\title{
JUDICIAL BARRIERS TO FARM DEBT RELIEF
}

Axrovg the innovations in American jurisprudence resulting from the economic stresses of the nineteen-thirties, probably none has been more strange to the courts than that expressed in former Sections 75, 77 and $77 \mathrm{~B}$ of the Bankruptcy Act, which treat the bankruptcy process not primarily as a method of liquidating the property of the debtor, but of salvaging and conserving the debtor's business enterprise. Of the three, Section 75, designed to relieve the hard-pressed farmer, has been accorded the stormiest reception. Originally passed in $1933^{2}$ to facilitate composition agreements between farmer and creditor, it proved so ineffective that Congress in the succeeding year saw fit to bolster the act by the addition of subsection $75(\mathrm{~s})$, the Frazier-Lemke Farm Moratorium Act. ${ }^{3}$ But the compulsory five-year extension of debts, the scaling down of mortgage debts to the appraised value of the security; and other elements composing this subsection were found by the Supreme Court to constitute a taking of the creditors' property without due process of law. ${ }^{4}$ Congress hastily amended the act, ${ }^{5}$ softening its provisions sufficiently to gain the acquiescence of the Supreme Court $;^{8}$ and later the operation of the amended act was extended to March 4, 1940. Although the basic scheme of the law has been sustained, many of its features have been severely battered on the rocks of judicial interpretation, partly because of inherent obscurity in the phrasing of the statute and partly because of an unduly strict and in some cases apparently hostile attitude on the part of the courts. Perhaps as a result, in over two years less than one per cent of the nation's farmers, according to estimate, have taken advantage of Section 75.8

The provisions of the statute and the question of its constitutionality have been the subject of extensive analysis and comment elsewhere ${ }^{0}$ and will not be treated here. But in view of the practical certainty that Congress will feel compelled to continue to relieve the farmer from the severities of a creditor economy, either by the further extension of the present Section 75 or by some other very similar means, it seems profitable to indicate the areas where the

1. 47 Stat. 1470 (1933), amended, 48 Stat. 1289 (1934), 49 St.it. 942 (1935), 52 Stat. 84, 11 U.S. C. A. $\$ 203$ (Supp. 1938).

2. 47 Stat. 1470 (1933).

3. 48 Stat. 1289 (1934).

4. Louisville Joint Stock Land Bank v. Radiord, 295 U. S. 555 (1935).

5. 49 Stat. 942 (1935).

6. Wright v. Vinton Branch of Miountain Trust Bank, 300 U.S. 440 (1937).

7. 52 Stat. 84 (1938).

8. See Hearings before the Sulcommittee on Banlruptey of the Heuse Itticiary Committee on S. 2215 and H. R. 6452. Dec. 17-18, 1937 and Jan. 5-7, 1938, cited hereafter as Hearings, p. 46. See also note 96, infra.

9. Diamond and Letzler, The New Frasier-Lemke Aet: A Strdy (1937) 37 CoL L. Rev. 1092; (1937) 37 CoL. L. Rev. 1005; (1937) 32 ILL. L. Rev. 239; (1937) 23 V.. L. Rev. 944; (1938) 23 Mrrx. L. Rev. 371. 
legislative intent has apparently been defeated, and to hazard an explanation of these reversals.

The procedure established by the Act may be briefly summarized. A farmer in distress may file a petition for relief in a district court, and thereupon all proceedings against him, as well as the running of any period of redemption where his mortgage has already been foreclosed, are stayed.10 The court refers the petition to a conciliation commissioner, who attempts to work out a plan of "equitable and feasible" liquidation for secured creditors and "financial rehabilitation" for the debtor. ${ }^{11}$ If such a plan is accepted by the creditors, and if the court is satisfied that the proceedings have been conducted in "good faith," the plan is confirmed. ${ }^{12}$ But if the creditors will not agree to a plan, or if the debtor is "aggrieved" by the plan confirmed, the Frazier-Lemke Act comes into operation. The debtor files an amended petition, asking for adjudication as a bankrupt. ${ }^{13} \mathrm{He}$ is thereupon entitled to a three year stay of all proceedings, and to an appraisal of his property. He must pay into court a semi-annual rental, equivalent to the customary rental in the locality, from which taxes and interest must be met; and he is subject to certain discretionary powers of the court, designed to safeguard the creditor's security. ${ }^{14}$ At the end of the three years, or at any time in the interim, he may receive a discharge in bankruptcy by paying into court the appraised value of the farm $;^{15}$ but at any time that such a payment is offered, the creditor may force a judicial sale. If the debtor is unable to. refinance himself within three years, the court may order the proceedings terminated. ${ }^{16}$

Two or three difficulties raised by the lower courts have already been removed by action of Congress or the Supreme Court, and need only briefly be noted here. The definition of those who may take advantage of the act has been broadened, in the face of a tendency in the lower courts to a narrow construction. ${ }^{17}$ As the statute was originally worded, ${ }^{18}$ it failed to convince

10. Bankruptcy Act $\$ 75(\mathrm{c})$, (n), (o), 47 Stat. 1470 (1933), as amended 40 Stat. 942 (1935), 11 U.S. C. A. \$203(c), (n), (o) (Supp. 1938).

11. $\$ 75(\mathrm{~b}),(\mathrm{e}),(\mathrm{f}),(\mathrm{g}),(\mathrm{h}),(\mathrm{i})$.

12. $\$ 75(\mathrm{i}),(\mathrm{j}),(\mathrm{k})$.

13. $\$ 75(\mathrm{~s})$.

14. $\$ 75(\mathrm{~s})(2)$.

15. Either creditor or debtor may call for a re-appraisal at any time, if he thinks the one fixed at the outset of the stay no longer represents the true value of the property. $\$ 75(s)(3)$.

16. $\$ 75(\mathrm{~s})(3)$.

17. The statute was amended [49 STAT. 246 (1935)] to cover dairy farmers and livestock and poultry producers. The Supreme Court has held that the debtor must, as the statute provides, be "personally engaged" in the enumerated operations, or deriving; the principal part of his income from them, but that he need not meet both requirements. First National Bank v. Beach, 301 U. S. 435 (1937); see Comment (1938) 4 Orio Srutt: L. J. 347.

18. "The filing of a petition . . . shall subject the farmer and his property . . . to the exclusive jurisdiction of the court." $\$ 75(n)$. 
many courts that property already sold under foreclosure proceedings was within the compass of the act, for they held that the right to redeem was an insufficient property interest to support bankruptcy proceedings. ${ }^{10}$ Congress therefore amended the statute to clarify the point.9 But the courts promptly countered with decisions that the extension of the redemption period involved in the stays granted was unconstitutional, in that it took the creditor's property without due process of law, and interfered with property rights established by state law. ${ }^{21}$ These decisions have now been reversed by the Supreme Court. $^{22}$ Mr. Justice Reed declared that the tolling of the redemption period is a regulation of the debtor-creditor relationship implicit in the bankruptcy power, and that state-fixed property rights might be altered in this manner provided they were not destroyed. ${ }^{23}$

Elsewhere the attempts of Congress to aroid particular difficulties have failed. Thus, legislative efforts to answer the question as to when proceedings against the debtor are automatically stayed and when he must have a court order to stay them ${ }^{24}$ have not cleared away the confusion. The settled federal rule is now that the filing of the first petition automatically stays proceedings, as provided in subsection (o), but that after "disposition" of the petition a judicial stay must be obtained..$^{25}$ It is not clear, however, whether action by the Conciliation Commissioner can constitute "disposition," or whether the filing of the amended petition marks the expiration of the

19. In re Knauft, 10 F. Supp. 785 (N. D. Cal. 1935); In re Chabuya, 9 F. Supp. 174 (S. D. Cal. 1934) ; cf. In re Nelson, 9 F. Supp. 657 (D. S. D. 1935); In re Falser, 11 F. Supp. 555 (D. Wash. 1935). Contra: In re Kalina, 9 F. Supp. 170 (D. Neb. 1935).

20. "The filing of a petition . . . shall subject the farmer and all his property" ... including the right or the equity of redemption . . . to the exclusive jurisdiction of the court. The period of redemption . . . shall be extended . . . for the period necessary for the carrying out of the purposes of this section." $\$ 75(n)$.

21. In re Lowmon, 79 F. (2d) 887 (C. C. A. 7th, 1935); In re Wright, 91 F. (2d) 894 (C. C. A. 7th, 1937); cf. In re Nossman, 22 F. Supp. 645 (D. Kan. 1938). Contra: Hoyd v. Citizen's Bank of Albany, 89 F. (2d) 105 (C. C. A. 6th, 1937).

22. Wright v. Union Central Life Ins. Co., 304 U. S. 502 (1938), rev'. In re Wright, 91 F. (2d) 894 (C. C. A. 7th, 1937).

23. The Court also held that the filing of the amended petition constituted "adjudication," and was the "line of cleavage" which determined how much of the debtur's progerty was within the jurisdiction of the bankruptcy court, some of the land having leen conreyed to him after the commencement of the bankruptey pruceeding. Iliid.

24. $\$ 75(n)$ provides that the filing of a petition shall subject the farmer and all his property, including contracts for purchase, contracts for sale, and equities of redemption to the exclusive jurisdiction of the court. A separate paragraph provides that the period of redemption shall be extended as long as necessary for the purposes of the section. Subsection (o) lists six types of proceedings which "shall not lie instituted . . . or maintained." Paragraph 2 of subsection ( $s$ ) provides that after the amendcd petition is filed and the conditions of paragraph 1 are complied with, the cuurt shall order a stay of all proceedings.

25. Hardt v. Kirkpatrick, 91 F. (2d) $\$ 75$ (C. C. A. 9th, 1937), cerf. domid, 303 U. S. 626 (1938) ; In re Price, 99 F. (2d) 691 (C.C. A. 7 th, 1938) : of. In re Pate, 99 F. (2d) 694 (C. C. A. 7 th, 1938). 
automatic stay. ${ }^{26}$ The Wisconsin Supreme Court has ruled that there is no automatic stay at all, ${ }^{27}$ on the ground that purchasers at a judicial sale without notice of an automatic stay should not be burdened with the risk that the sale might be illegal. While this argument is plausible, in internal evidence in the statute ${ }^{20}$ seems to indicate that the Federal rule is the better expression of the legislative intention. ${ }^{30}$ It is true that due care on the part of the debtor's attorney in getting a judicial stay at all points will adequately protect the debtor, but presumably those sought to be protected will not have the best of legal advice.

Perhaps the most ill-fated of all the provisions of subsection ( $s$ ) has been paragraph 5. In the first place, it was there provided that "Any farm debtor who has filed under the General Bankruptcy Act may take advantage of this section upon written request to the court; and a previous discharge of the debtor under any other section of this act shall not be grounds for denying him the benefit of this section." 31 Extrinsic evidence is lacking as to the intention of Congress in framing this sentence. But it appears to have been uniformly held, contrary to the first impression received from the words of the statute, that a proceeding already commenced in general bankruptcy can-

26. Compare In re Cresap, C. C. H. Bankr. Senv. 1 51, 445 (C. C. A. 7th, 1938) with Hardt v. Kirkpatrick, 91 F. (2d) 875 (C. C. A. 9th, 1937); cf. In re Rank, 9 F. Supp. 171 (D. Neb. 1934). Obviously the stay must terminate upon the failure of the composition proceedings if the debtor does not amend. The statute does not fix an exact time within which an amended petition must be filed, and it is therefore not clear how long after the failure of the negotiations the stay extends.

27. ' Kalb v. Luce, 279 N. W. 685,280 N. W. 725 (Wis. 1938), dismissed fur want of final judgment by U. S. Supreme Court, Oct. 24, 1938 (59 Sup. Ct. 107). The earlicr opinion is grounded on what seems an erroneous reading of Hardt v. Kirkpatrick, $91 \mathrm{~F}$. (2d) 875 (C. C. A. 7th, 1937), but the later one shifts to public policy for its principal support. It may be noted that the debtor's relief would have been barred even under the Federal rule, because his automatic stay had expired, so that the Wisconsin court's ruling is not necessary under the facts of the case.

28. The automatic stay would not appear on the abstract of title, as a jutlicial stay would.

29. The passive tense employed in subsection (o) ("The following procedings slatl not be instituted . . . or maintained"), and the fact that, if the stay there provided is not automatic, subsection $(o)$ is superfluous in view of the judicial stay provided in subsection ( $\mathrm{n}$ ), tell against the view taken by the Wisconsin court.

30. There seems no justification, however, for the extension of the Hardl z', Kirl:patrick rule made in In re $\mathrm{Cox}, 22 \mathrm{~F}$. Supp. 925 (D. Idaho 1938). In that case a debtor who filed her original petition two days before the expiration of the redemption period, but when filing her amended petition neglected to get an express order from the court staying the running of the redemption period, lost her property upon the expiration of two days. The ruling maintains that the running of the period of redemption is a "proceeding" stayed by subsection (o) only until the disposition of the original petition; but since a separate part of the statute is responsible for extending the redemption period, there seems no valid reason of policy or logic why the cessation of the automatic stay should operate with respect to the redemption period.

31. 49 Stat. 945 (1935), 11 U. S. C. \$203(s) (5) (Supp. 1936). 
not, after adjudication, be transformed into a Section 75 proceeding. 32 The reason given is that, when his property has once come into the possession of the trustee in general bankruptcy, the debtor no longer owns property sufficient to support proceedings under Section $75 ; 33$ while to interfere with the rights of the creditors which vest when the trustee takes title would violate the Fifth Amendment. ${ }^{34}$ Some courts have held, however, that the acquisition of property after adjudication in general bankruptcy will enable the debtor to maintain the two kinds of proceeding simultaneously, 35 and one court has allowed the debtor to naintain Section 75 procecdings with regard to property abandoned by the trustee, where the mortgagee has not proceeded to acquire vested rights therein. ${ }^{36}$ While the majority rule seems firmly established, the purpose of Section 75 was to preserve the debtor's interest in his land and promote individual ownership; and the effect of the rule is to save for a general bankrupt only that land which he acquires after adjudication. Further, such a restriction seems to make the statutory provision almost superfluous, for the debtor could presumably enjoy Section 75 relief for after-acquired land even in the absence of such a provision.

The question of the effect of a previous discharge has not been extensively litigated, but in one case the court declared that a previous discharge would be grounds for denying no benefits $e^{x} c^{2} p t$ another discharge within six years. ${ }^{37}$ The words of paragraph 5 make no such exception in denying any effect to a previous discharge; but the court does not mention paragraph 5 in its opinion, for it apparently considers Section 14 of the $\mathrm{Act}^{39}$ as controlling. If this dictum becomes the established rule, its presumable effect will be to make the practice under Section 75 similar to that under general bankruptcy, and to render the provision of paragraph 5 nugatory, for even in general bankruptcy practically the only relief barred by a previous discharge is another discharge within six years. ${ }^{39}$

32. Pearce v. Coller, 92 F. (2d) 237 (C. C. A. 3d, 1937), cert. denicd, 302 U. S. 745 (1938) ; Hostetter v. New York Joint Stock Land Bank, 84 F. (2d) 389 (C. C. A. 3d, 1936) ; see In re Reichert, 13 F. Supp. 1,7 (W. D. Ky. 1936); (1937) 37 CoL. L. REy. 1101. But in the Eighth Circuit mere proof that a debtor was proceeding under Section 74 (providing for compositions and extensions) does not without more preclude relief under Section 75. Summers v. Collector of Taxes of Scotland County, 34 Am. B. R. (N.s.) 24, 34 Am. B. R. (N.s.) 728, 92 F. (2d) 819 (C. C. A. Sth, 1937 ).

33. See Pearce v. Coller, 92 F. (2d) 237, 238 (C. C. A. 3d, 1937).

34. See In re Reichert, 13 F. Supp. 1,7 (W. D. Ky. 1936).

35. In re Reichert, 13 F. Supp. 1 (IV. D. Ky. 1936); In re MeIntyre, 17 F. Supp. 914 (W. D. Pa. 1936).

36. In re AIcIntyre, 17 F. Supp. 914 (W. D. Pa. 1936); see In re Mloss, 21 F. Supp. 1019, 1020 (E. D. Ill. 1938).

37. See In re MicIntyre, 17 F. Supp. 914, 916 (W. D. Pa. 1936).

38. "The court shall grant the discharge unless satisfied that the bankrupt has . . . within six years prior to bankruptcy been granted a discharge." 32 Sr.1. 797 (1903), 11 U. S. C. $\$ 32$ (1934).

39. Of course, it must be remembered that whereas the discharge is the main and immediate object of the debtor in a general bankruptey proceeding, under Section 75 
The other portions of paragraph 5 , which attempted to avert the effect of the Radford case $^{40}$ by providing that petitions dismissed because of that decision "be promptly reinstated," have met a similar fate. If they were designed to restore the status quo before the Radford decision, they have not accomplished their purpose. It has been held that those who acquired rights in the debtor's property during the interregnum when there was no Frazier-Lemke Act cotild not be divested of those rights thereafter, whether they were acquired by foreclosure, ${ }^{41}$ by contract, ${ }^{42}$ or even by misrepresentation. ${ }^{43}$ And the majority of courts held that the debtor must take some positive action to get his proceeding reinstated,44 though just what that action should be was never settled. ${ }^{45}$ On March 3, 1938, the Act was amended to cover cases dismissed by the lower courts under the impression that the new Frazier-Lemke Act was unconstitutional $;^{46}$ but even this amendment seems to have been of no avail. ${ }^{47}$ The debtor most immediately threatened by foreclosure is apparently the one Congress is least able to protect from the effect of the invalidation of the statute, despite its best efforts to that end.

While these difficulties will disappear with time, and the problem of a transfer from general bankruptcy will become much less acute as the constitutionality of Section 75 becomes settled and the debtor is enabled to elect

it is only an incident to the three year stay and subsequent retention of the property by the debtor. Hence, the denial of a second discharge is not there so serious.

40. Louisville Joint Stock Land Bank v. Radford, 295 U. S. 555 (1935).

41. Shreiner v. Farmers' Trust Co., 91 F. (2d) 606 (C. C. A. 3d, 1937); DuBose v. First Carolinas Joint Stock Land Bank, 83 F. (2d) 97 (C. C. A. 4th, 1936) ; Barton v. Gehman, 91 F. (2d) 548 (C. C. A. 3d, 1937); cf. In re Leinweber, 95 F. (2d) 240 (C. C. A. 7th, 1938).

42. Rehmeyer v. First National Bank of New Freedom, 84 F. (2d) 194 (C. C. A. 3d, 1936).

43. In re Byerly, 20 F. Supp. 762 (S. D. Ohio 1937). Such a claim of misrepresentation could be tested only in a plenary suit and not in the bankruptcy procecling. In rc Merritt, 19 F. Supp. 112 (N. D. Cal. 1937).

44. In re Suzuki, 20 F. Supp. 900 (S. D. Cal. 1937) ; In re Byerly, 20 F. Supp. 762 (S. D. Ohio 1937). But of. In re Oyler, 20 F. Supp. 595 (S. D. Ohio 1936). In In $r c$ Leinweber, 95 F. (2d) 240 (C. C. A. 7th, 1938), it was held that the failure of the debtor to reinstate "promptly" may, with other things, constitute laches and estoppel when he does file a petition.

45. Compare In re Oyler, 20 F. Supp. 595 (S. D. Ohio 1936), and $I n$ re Archibald, 14 F. Supp. 437 (D. Minn. 1936), with Diller v. Shoemaker, 90 F. (2d) 98 (C. C. A. 9th, 1937). See Hearings, p. 64, for account of another procedure.

46. 52 Stat. 84 (1938).

47. Reber v. Home Owners Loan Corp., 96 F. (2d) 77 (C. C. A. Sth, 1938); of. McWilliams v. Blackard, 96 F. (2d) 43 (C. C. A. Sth, 1938), where although there was no question of third parties' rights involved the court refused to reinstate on the ground that an erroneous decision not appealed was res judicata. The court was apparently unaware that the statute had been specifically amended to prevent such a result. In the Reber case the statute is not mentioned, but the court rests on the ground of vested rights in third parties much as did the courts which refused to reinstate actions under the unamended statute. 
the proper remedy in the first place, there are other more permanent judicial obstacles to farm debt relief with which Congress has not yet dealt. Among these is the rule that in some cases the dismissal of one proposal for composition and extension will be res judicata as to succeeding proposals. In its application this restriction may not be unreasonably harsh on the deltor. As laid down by the Ninth Circuit, the rule is that the creditor seeking dismissal of the new petition must sustain the burden of proof that no change in the debtor's position has occurred sufficient to justify a new proceeding ${ }^{45}$ A district court in California has held, however, that where the original petition was abandoned by the debtor the new petition must show on its face a change sufficient to preclude dismissal. ${ }^{49}$ And a Minnesota district court has gone so far as to rule all dismissals res judicata ${ }^{\text {to }}$-a harsh and unnecessarily comprehensive doctrine, especially since it results from a case involving seemingly innocuous action on the part of the debtor. ${ }^{51}$ It is to be hoped that the Ninth Circuit rule will be recognized as desirable in cases where the original petition is dismissed for lack of good faith. If the debtor can float a loan or otherwise improve his prospects, he should be permitted to try again to effect a composition, or to persuade the court that he is capable of rehabilitation. And even in the case where the original petition has been abandoned, no great hardship will be worked by extending the Ninth Circuit rule so as to require the creditor to show why the debtor should not be permitted a second attempt.t? The courts seem to be somewhat fearful of the specter of a debtor filing petition after petition, with an automatic stay accompanying each one, and thus holding off his creditors ad infinitum. Such a remote contingency, if it actually occurred, could presumably be met with injunctive relief.

Probably the most disliked and most sweeping bit of judicial interpretation has been the expansion of the "good faitl" requirement of subsection 75(i) into the largest single barrier to relief under the act. 33 Section 75 provides, briefly, that a proposal for the composition and extension of the farmer's debts shall be confirmed by the court if filed "in good faith, and not . . . made or procured except as herein provided, or by any means, promises, or acts herein forbidden"; if presenting an "equitable and feasible method

48. Howell v. Federal Land Bank of Spokane, 92 F. (2d) 703 (C. C. A. 9th, 1937); Lemm v. Northern California National Bank, 93 F. (2d) 709 (C. C. A. 9th, 1937).

49. In re Suzuki, 20 F. Supp. 900 (S. D. Cal. 1937).

50. In re Archibald, 14 F. Supp. 437 (D. MIinn. 1926).

51. The debtor had failed to reach an agreement with his creditors, omitted to amend, and then filed a new petition. The failure to amend occurred during the interregnum between the Radford decision and the amended act of Aug. 28, 1935, and was presumably due to the then extreme uncertainty of the law.

52. The Seventh Circuit has recently ruled that a voluntary dismissal of the first petition will be no bar to a second. In re Armold, 100 F. (2d) 621 (C. C. A. 7th, 1933). The court apparently did not consider the objections raised in the ather cases. It is to be noted that this case and the cases cited notes 48-50 supro, when chronologically arranged, show steadily increasing leniency.

53. See Hearings, particularly the testimony of William Lemke and Elmer MrClain. 
of liquidation for secured creditors and of financial rehabilitation for the farmer"; and if accepted by a majority, in number and amount, of the creditors. ${ }^{54}$ Subsection ( $\mathrm{s}$ ), the Frazier-Lemke Act, provides that a debtor who fails to get the consent of his creditors, or is aggrieved by the plan to which they consent, may amend his petition, be adjudged bankrupt, and then be entitled to a three-year stay of all proceedings against his farm property, within certain limits. It is questionable whether the "good faith" provision of subsection (i) was meant ever to refer to circumstances other than those conjunctively mentioned, plus fraud and misrepresentation; but at least it seems certain that the "good faith" requirement was not intended to apply to proceedings under subsection (s). ${ }^{55}$ The debtor was to be given "the absolute legal right to amend" 56 his petition and enjoy the three year stay. Yet the courts have almost uniformly denied him both the power to amend and the benefits of the moratorium, where the original composition proposal was not made in "good faith," 57 a term which has been variously and in some cases very strictly interpreted. While the Supreme Court has never expressly approved or disapproved this "good faith" requirement, a note to Mr. Justice Brandeis' opinion in Wright v. Vinton Branch of Mountain Trust Bank, ${ }^{58}$ where the present subsection (s) was held constitutional, states the doctrine concisely. But foes of the doctrine deny that this note constitutes approval by the Court, ${ }^{59}$ and at least it would not conclude the Court were the issue to be directly presented.

Even were the Supreme Court to rule that the debtor has unlimited power to amend his petition to come under subsection (s), the barrier to the farmer's relief would not necessarily be removed. The Court in the $I V$ right case interpreted the statute as giving the courts discretionary power to terminate the three year stay at any time. ${ }^{B 0}$ There has been apparent in recent cases a tendency to employ as standards in the exercise of that discretion the standards

54. $\$ 75(\mathrm{~g}),(\mathrm{i})$.

55. See Hearings, pp. 5-7, 190.

56. See Brief of William Lemke for Appellant, p. 12, Bender v. Federal Farm Mortgage Corp., 99 F. (2d) 252 (C. C. A. 8th, 1938).

57. Apparently the only cases contra have been $I n r e$ Moser, 95 F. (2d) 944 (C. C. A. 9th, 1938), and Bartels v. John Hancock Mutual Life Ins. Co., 100 F. (2d) 813 (C. C. A. 5th, 1938). The latter decision, however, was handed down on the same day as an exactly contrary decision by the same court, sitting with a differently composed bench. In re Henderson, $100 \mathrm{~F}$. (2d) 820 (C. C. A. 5th, 1938). Moreover, it is not clear from the language of the Moser case whether the decision-that the question of good faith is moot when the debtor amends to come under subsection (s)-affects substance or procedure. If the latter, it may still be possible for the creditor to have the proceedings dismissed for want of good faith, at least in jurisdictions where he may move for dismissal at any time. See cases cited infra, notes 78, 79.

58. 300 U. S. 440,462 n. (1937).

59. See Brief of William Lemke for Appellant, Bender v. Federal Farm Murtgage Corp., 99 F. (2d) 252 (C. C. A. 8th, 1938).

60. Wright v. Vinton Branch of Mountain Trust Bank, 300 U. S. 440,462 (1937). 
of dismissal laid down in the "good faith" cases."11 Indeed, the above mentioned footnote to the Wright case may be read to suggest such a transfer of standards. Since it can be of little concern to the farmer whether his petition is "dismissed for lack of good faith" or his stay terminated immediately after adjudication, it seems that any attempt to rectify the present situation should be directed not toward abolishing the "good faith" rule as applied to subsection (s), but toward relaxing and defining the standards of good faith.

The present range of judicial rulings on good faith is wide. The farmer in northern Texas ${ }^{62}$ or eastern Illinois, ${ }^{03}$ it appears, is entitled to his three year stay as long as he can keep up the farm and pay into court a rental, equivalent to the customary rental in the locality, from which the taxes can be met and some interest paid to the creditor. His brother in North Dakota, ${ }^{\text {th }}$ on the other hand, has been refused the benefits of the act unless he presents a definite, unconditional, and feasible plan for payment in full of his secured debts. Between these extremes lie several intermediate positions. One of the more frequent is that which denies to the debtor the privilege of petitioning for relief under Section 75(s) where the composition and extension proposal refused by his creditors was obviously less favorable to them than the Section $75(\mathrm{~s})$ proceedings would be. ${ }^{65}$ The argument is to the effect that subsection (s) was merely an inducement to creditors to accept the composition proposal, the main object of Section 75 being to foster agreements between debtor and creditor. ${ }^{60}$ Consequently a debtor who attempts to short-cut subsections (a) through ( $r$ ) by putting forward an unacceptable proposal is acting in bad faith and will be turned out of court. This seems a fair enough requirement, if objective standards are employed to determine whether the debtor's offer is one which could reasonably have been accepted. But the framers of the act apparently did not intend that the mere inadequacy of a proposal should furnish grounds for dismissal of the entire action."7 Subsection (s), with its three year stay, was thought of as the debtor's principal remedy; the preceding subsections were retained in order that ill will between debtor and creditor might be avoided by inducing the creditor to consent to

61. E.g., In re Dandy, 23 F. Supp. 361 (W. D. S. C. 1938); In re Andersun, 22 F. Supp. 928 (D. N. D. 1938) ; In re Reynolds, 21 F. Supp. 369 (D. Okla. 1937 ).

62. In re Slaughter, 12 F. Supp. 206 (N. D. Tex. 1935), reid on further shoring of facts, 13 F. Supp. 893 (N. D. Tex. 1936); cf. In re Bumpass, 23 F. Supp. 876 (N. D. Tex. 1938). The latter case did not arise on the point of good faith, but tends nerertheless to show the standards required of the debtor.

63. In re Anderson, 23 F. Supp. 854 (E. D. Ill. 1938 ).

64. Bender v. Federal Farm Mortgage Corp., 99 F. (2d) 252 (C. C. A. Sth, 1938 ).

65. Baxter v. Savings Bank of Utica, 92 F. (2d) 404 (C.C.A. 5th, 1937): sse In re Palmer, 21 F. Supp. 628, 632 (D. N. D. 1937) : In re Vater, 14 F. Supp. 631, 632 (W. D. Ky. 1936) ; In rc Hilliker, 9 F. Sufp. 948, 950 (S. D. Cal. 1935 ).

66. See Baxter v. Savings Bank of Utica, 92 F. (2d) 404,406 (C. C. A. 5th, 1937).

67. See Hearings, pp. 5-7, 190. 
a voluntary composition. ${ }^{68}$ Congress, perhaps, has only itself to blame if its words have been misinterpreted in this instance; yet the almost incredible declaration of one court, that the announced indisposition of the farmer's creditors to consider any composition proposal required the dismissal of the proceedings for want of good faith on the part of the farmer, ${ }^{60}$ reveals the unreasonable extent to which the "inducement" theory can be carried.

A second rule which emerges with some clarity is the holding of many courts that the debtor to show his "good faith" must present a plan of rehabilitation which is definite and unconditional. ${ }^{70}$ The submission of plans contingent upon securing loans from banks, ${ }^{71}$ or upon other refinancing arrangements which are not certain, is considered unsatisfactory. This standard, it seems, could be used to throw the debtor out of court, on the ground that he is unable to refinance himself, even if the "good faith" requirement were no longer enforced as a bar to adjudication; but no matter how it is employed it scems contrary to the legislative intent. Since the purpose of Section 75 was to shield the farmer from the worst effects of the depression, he should be allowed the full three years in which to arrange his loans, instead of being forced to do so at the height of the emergency which necessitated the moratorium.

Here, of course, the act treads upon the borderland of constitutionality. It was formerly thought that an out-and-out moratorium is beyond the power of Congress, although there are no express holdings on the point; ${ }^{72}$ and the amended Frazier-Lemke Act has been justified instead as an exercise of the bankruptcy power. ${ }^{73}$ It is possible that the courts which have promulgated the rule that the debtor's proposal must be unconditional have done so from an unexpressed belief that a delay without a definite plan of rehabilitation would be unconstitutional. If so, the point should be clarified and settled.

By far the most general criterion of good faith is that the debtor must propose an "equitable and feasible method of liquidation for secured creditors,"

68. Evidence that the composition proceeding was not the main object of the amended act is to be found in the provision that the debtor may amend despite the consent of his creditors to a composition plan if he is "aggrieved" by it.

69. See Knotts v. First Carolinas Joint Stock Land Bank, \&6 F. (2d) 551 (C. C. A. 4th, 1936), cert. denied, 300 U. S. 660 (1937). The statement, however, was merely a dictum thrown out in the process of holding the act unconstitutional.

70. See In re Dionne, 21 F. Supp. 311, 313 (D. Me. 1937) ; In rc Borgelt. 10 F. Supp. 113, 117 (S. D. I1l. 1935), aff'd, 79 F. (2d) 929 (C. C. A. 7th, 1935); cf. Massey v. Farmers \& Merchants Nat. Bank and Trust Co., 94 F. (2d) 526 (C. C. A. 4th, 1938); In re Byrd, 15 F. Supp. 453 (D. Md. 1936). But see In rc Kleve, C. C. H. Banzr. SzRv. \I 3406 (D. Minn. 1935).

71. In re Buxton's Estate, 14 F. Supp. 616 (E. D. I1l. 1936).

72. See Louisville Joint Stock Land Bank v. Radford, 295 U. S. 555, 597, 598 (1935); In re Slaughter, 13 F. Supp. 893, 894 (N. D. Tex. 1935); cf. In re Lowmon, 79 F. (2d) 887, 891 (C. C. A. 7th, 1935), overruled by Wright v. Union Central Life Ins, Co, 304 U. S. 502 (1938).

73. Wright v. Vinton Branch of Mountain Trust Bank, 300 U. S. 440 (1937). "Whether, in view of the emergency, an absolute stay of three years would have been justified under the bankruptcy power, we have no occasion to decide." Id. at p. 460. 
as well as "of financial rehabilitation" for himself. Within this general rule, however, variation again appears in the interpretation of "liquidation" and "rehabilitation." T4 Many courts, dismissing petitions curtly for failure to present such a plan, have not made clear in their published opinions what constitutes "liquidation" for secured creditors." Similarly Mrr. Justice Brandeis, in the Wright case, fails to discuss the point. Among the courts which have been more definite, three schools of thought have grown up. First come the. courts which hold or otherwise indicate that the debtor must have some "equity" in the property to assure the creditor that the latter's three-year wait shall not be a mere delay. ${ }^{76}$ Whether Congress did in fact intend that the stay should benefit the creditor as well as the debtor is doubtful, but in any case the standard is objectionable in that it lacks clarity. And if the mysterious "equity" be defined to mean an excess of assets over liabilities, as it has been in some cases, ${ }^{77}$ then the standard seems unduly strict. To require that the debtor own more than he owes is a strange requirement for what is at least labelled a "bankruptcy" proceeding.

The second rule is that which provides that the debtor must show a prospective ability to pay the appraised value of his farm, at the scheduled time if it is his composition proposal which is challenged, or at the end of three years if he is seeking relief under subsection ( $s$ ). ${ }^{78}$ This requirement is based on the statutory necessity of paying the appraised value within the three year period if the farmer is to retain the farm, but may work injustice in the difficulty of proving a prediction of future events. The third and by far the majority rule is that the proceedings must contemplate repayment of the secured creditor in full. ${ }^{79}$ The justification for this is the statutory privilege of the secured creditor to demand a judicial sale of the security and to bid as high as he wishes at the sale instead of accepting payment of the appraised

74. See cases cited infra nctss 76-79. The problem is well discucsed in In re Anderson. 22 F. Supp. 928 (D. N. D. 193S). (1938) 23 Mirs. L. Res. 37l, and In re Anderson, 23 F. Supp. 854, 856 (E. D. Ill. 1938).

75. E.g., In re Davis, 22 F. Supp. 12 (N. D. Iowa 1938 ).

76. See In re Davis, 16 F. Supp. 960, 961 (N. D. Tex, 1936); In re .Inder $n$, 22 F. Supp. 928, 933 (D. N. D. 1938).

77. See Pearce v. Coller, 92 F. (2d) 237, 239 (C. C. A. 3d, 1937) ; In re McGrew. 23 F. Supp. 159, 160 (W. D. Pa. 1937); In re Reynolds, 21 F. Supp. 369, 371 IW. D. Okla. 1937). If the requirement is that of a present or potential equity, as in Cowitcril v. Phoenix Joint Stock Land Bank, 99 F. (2d) 225 (C. C. A. 7th, 1938), then of cour it is equivalent to a requirement that the debt be eventually paid in full. Sce nutes 79,80 , infra.

78. In re Anderson, 23 F. Supp. 854 (E. D. Ill. 1938); sce Doak v. Federal Iand Bank of Baltimore, 99 F. (2d) 145, 146 (C. C. A. 4th, 1938), corl. denicd. 59 Sup (t. 253 (1938); In re Reaney, C. C. H. Bankr. Senv. T51,342 (V. D. Pa. 1938); af. In rit Anderson, 22 F. Supp. 928 (D. N. D. 1938).

79. Cowherd v. Phoenix Joirt Stock Iand Bank, 99 F. (2d) 225 (C. C. A. 8th, 1938) : I.emm v. Northern California National Bank, 93 F. (2d) 709 (C. C. A. 9th, 1937); In re Borgelt, 79 F. (2d) 929 (C. C. A. 7th, 1935); In re Schaeffer, 14 F. Supp. 807 (D. Md. 1936) ; In re Erickson, 18 F. Supp. 439 (IW. D. Mich. 1936). 
value. The argument runs that since he may bid up to the full amount owed him, the debtor must be prepared to pay in full.".

A choice between these three rules must be made with an eye to the threat of unconstitutionality. A reading of the Radford opinion creates the inpression that the debt must be paid in full. ${ }^{51}$ The Wright case, on the other haund, seems to indicate that the bankruptcy power will support the scaling dowu of the mortgagor's obligation to the value of the security, and that any reliet to the mortgagor is permissible provided the security remains unharmed.2. Since the security may never again bring the price at which it was mortgaged, and since it does not seem incompatible with the theory of bankruptcy proceedings to ask the creditor to bear the loss, the desirable standard wotld seem to be that of eventual ability to pay the appraised value, as prestumally distinguished both from the amount of the mortgage debt and from the stun that could be realized by immediate foreclosure. If it is constitutionally necessary that the prospective ability of the debtor to raise that sum be found helore he should be entitled to relief, at least the burden should be on the creditor to refute that prospective ability.

It is apparent that the farmer who falls under the jurisdiction of one of the stricter district courts has small hope of relief. Prior to 1938, the distinction between "controversies in bankruptcy", reviewable as of right both as to questions of fact and law, ${ }^{83}$ and "proceedings in bankruptcy", reviewable only by permission and only as to questions of law, ${ }^{84}$ was so applied in most cases as to limit the farmer's opportunity to appeal, on the ground that dismissal of his petition was a mere "proceeding". ${ }^{53}$ And good faith was appar-

80. Cf. Cowherd v. Phoenix Joint Stock Land Bank, 99 F. (2d) 225 (C. C. A. Sth, 1938). It has been suggested that a bid of more than the value of the security wotld nut only be foolishness but bad faith on the part of the creditor (Hearings, pp. 7-8): but the suggestion has not been well received by the courts. See In $r \varepsilon$ Anderson, $22 \mathrm{~F}$. Sutpp. 928, 936 (D. N. D. 1938).

81. Most of the courts taking the strict view of rehabilitation rely strongly oul the Radford case. See, e.g., Cowherd v. Phoenix Joint Stock Land Bank, 99 F. (2d) 2.5 (C. C. A. 8th, 1938).

82. See Wright v. Vinton Branch of Mountain Trust Bank, 300 U.S. 440, 466-418 (1937). For discussions of the act's effect and purpose, see Adair v. Bank of America, 303 U. S. 350, 354-357 (1938), and Wright v. Union Central Life Ins. Co., 304 U. S. 502. 514-518 (1938).

83. 30 Stat. 553 (1898), as amended, 43 St 4 r. 936 (1925), 11 U. S. C. $\$ 48$ (19.34).

84. 30 Sтат. 553 (1898), as amended, 43 Stat. 936 (1925), 11 U. S. C. $\$ 47$ (1934).

85. Dismissal after the filing of the amended petition was generally a "proceeding." In re Combs, 88 F. (2d) 417 (C.C. A. 2d, 1937); In $n$ Hargrove, 96 F. (2d) 168 (C.C. A. 5th, 1938); Griffith v. Equitable Assurance Society, 91 F. (2d) 9 (C.C. A. 8th, 1937). But compare Knotts v. First Carolinas Joint Stock Land Bank, 86 F. (2d) 551 (C. C. A. 4th, 1936) (dismissal before amended petition appealable by right), with Raentsch v. American Co., 82 F. (2d) 770 (C. C. A. 9th, 1936) (such dismiscals nut appealable by right in absence of express request for adjudication); (Cowherd v. Plinetiix Joint Stock Land Bank, 94 F. (2d) 329 (C. C. A. 8th, 1938) (no request necessary).

Before the Frazier-Lemke Act was amended in 1935, the filing of the original petition was generally held to be the time after which dismissals were mere "priceedings." 
ently a question of fact, supposedly not reviewable on a permissive appeal. ${ }^{86}$ The Chandler Act has remedied that state of affairs by making all appeals alike, ${ }^{8 \pi}$ but the reluctance of the courts to grant appeals in forma paupcris has been assailed as in effect denying the farmer the right of appeal. ${ }^{83}$ Moreover, a foreclosure or other disposal of the property pending the appeal apparently makes the latter moot. ${ }^{\mathrm{s}}$

The farmer who can pass the "good faith" barrier, on the other hand, seems to be fairly safe for the duration of his three years. The statute provides that "if the debtor is unable to refinance himself within three years" the court may" terminate the stay $;^{30}$ and the Supreme Court has interpreted this power as within the court's discretion to exercise at any time.91 But except where the stay has been "terminated at the outset" for failure to present a definite plan of rehabilitation, the courts have been somewhat reluctant to exercise their admitted discretion. Only where the debtor has not paid the prescribed rental ${ }^{\circ 2}$ or where he has obviously exceeded the bounds of propriety, as by attempting to sell the property to an innocent purchaser, ${ }^{93}$ or by abandoning farming for real estate subdivision, ${ }^{94}$ will the court expel him from possession.

The judicially created obstacles to farm debt relief noted above must be held responsible in no small degree for the charges of ineffectiveness hurled against Section 75.95 One estimate has fixed the number of those farmers

Wilkerson v. Cooch, 78 F. (2d) 311 (C. C. A. 9th, 1935); In re Harris, is F. (2d) \$49 (C. C. A. 9th, 1935).

86. In Augustyn v. John Hancock Mrutual Life Ins. Co., 87 F. (2d) 577 (C. C. A. 7th, 1937), good faith was held to be a question of fact under the parallel and almost identically worded subsection of $\$ 74$. This was followed in O'Connor $\mathrm{v}$. Miills, $90 \mathrm{~F}$. (2d) fits, 666 (C. C. A. Sth, 1937), as to a much less similar phrasing in $\$ 77 \mathrm{~B}$. The point has never been directly raised under $\$ 75$. The circuit courts have not been averse to discus $4-$ ing the facts of the cases, but on the other hand they have almost always sustained tire district courts where good faith was the point in issue. In the absence of evidence in tise record on good faith, a presumption favors the tinding of the district court. Bank of Eureka v. Partington, 91 F. (2d) 587 (C. C. A. 9th, 1937).

87. 52 Stat. 854 (1938), 11 U. S.C.A. $\$ 47$ (Supp. 1938). It has been suggested that the distinction still persists with regard to interlatutory orders. See Wersstes. THE BAXKKRUPTCY LAW of 1938 (1938) 66.

88. See Hearings, pp. \&-9, 68-69, 93.

89. Noll v. Union Joint Stock Land Bank, S4 F. (2d) 56s (C. C. A. 3d, 1036).

90. 49 Stat. 942 (1935); 11 U. S. C. $\$ 203$ (s) (3) (Supp. 1936).

91. See Wright v. Vinton Branch of Mountain Trust Bank, 300 U. S. 440, 462 (1937).

92. In re Chilton, 18 F. Supp. 937 (D. Colo. 1939). In such a case the statute expressly permits termination. $\$ 75(\mathrm{~s})(3)$. There is no equity of redemption after suci a sale In re Chilton, supra.

93. In re Prudhomme, 24 F. Supp. 155 (W. D. La. 1938).

94. In re Farr, 23 F. Supp. 945 (W. D. S. C. 1938); cf. In re Mfaricelli, 24 F. Sufp. 66 (W. D. La. 1938) (farmer getting deeper in debt).

One court, however, has denied that it possesses any power of termination within the three years. In re McIntyre, 23 F. Supp. 343 (W. D. Pa. 193S).

95. See Hearings, especially statements of Peyton R. Evans, pp. 75-133, and Jacob I. Weinstein, pp. 14-43. 
who between August 28, 1935, and December 15, 1937, were actually able to avail themselves of subsection (s) at $00.003 \%$, or less than seventy-five farmers, of the 2,350,000 with mortgaged farms. ${ }^{06}$ While this calculation of course does not take into account the compositions arrived at, whether in or out of court, under the threat of an imminent proceeding under subsection (s), ${ }^{97}$ there is no doubt that the act has not been as widely involed as its framers expected..$^{98}$ In such a situation it is not altogether easy to determine whether the strictness of the courts has excluded too many debtors, or whether the failure of all but the chronically impecunious to apply has brought about the strict decisions; but the facts seem to support the former view. The causes behind the harshness and confusion of the courts can only be a matter of conjecture. Obviously excessive care to avoid the pitfalls of unconstitutionality, ${ }^{90}$ and hasty draftsmanship of the statute, resulting in ambiguous wording, have been responsible for a great deal of the difficulty. But some of the caluses of irritation are more fundamental. For example, the failure of paragraph 5 of subsection (s) to achieve its apparent object of restoring the status quo before the invalidation of the Frazier-Lemke Act must be laid to a collision of the legislative intent with the settled practices of the common law with regard to rights which have once vested. Another potent source of trotible has been the conflict between the notions of liquidation and conservation. Section 75 has been created and sustained as a bankruptcy proceeding, not an equity receivership or a moratorium; ;00 but some unexpressed remnant of such a theory must account for the requirements of eventual debt satisfaction, or of the presence of some "equity" over and above liabilities, which have been enforced in some cases. Finally, there has been the ancient judicial sin of laying down rules too broad for the facts of the particular case. This has been particularly apparent in some of the good faith cases, where the courts seemingly suspected actual skullduggery on the part of particular debtors, and swept them out of court with a broom so large as to catch innocent deltors thereafter.

None of these difficulties is insuperable. A clear, definitive exposition of the law, both as to fundamental theory and as to practical details of operation,

96. Statement of Peyton R. Evans, General Counsel, Farm Credit Administration, Hearings, p. 87.

97. See Hearings, pp. 165-183.

98. As of June, $1937,14,899$ petitions had been filed under $\$ 75 ; 8,864$ had beell dis:missed; 3,852 were then pending; and only 2,183 had proceeded to a conclusion. Hearint/s. p. 12. For later statistics, see pp. 201-203; for a more detailed analysis, sce pp. 38-42.

99. Indeed, it may almost be said that the existence of the good faith rule is dic to the interpretation of the statute, but that its harshness and unpopularity are duc to the interpretation of the Constitution.

100. See Wright v. Union Central Life Ins. Co., 304 U. S. 502, 515-518 (1038): Wright v. Vinton Branch of Mountain Trust Bank, 300 U. S. 440, 469-470. "The procecele ings under . . Section 75 ... are not the equivalents of equity receivership procec(ings." In re Sterba, 74 F. (2d) 413, 417 (C. C. A. 7th, 1935). 
is not beyond the capacity of the Supreme Court. The act is now set to expire in 1940, but it is quite likely that it, or some similar measure, will be in operation an indefinite number of years. That it is labelled an emergency measure will not necessarily prevent its extension as long as the evil whose threat it was designed to check continues. ${ }^{101}$ And the menace of farm tenancy in this country continues to grow. In 1880 one fourth of American farmers were tenants; in 1900 one third; in 1930 almost one half. ${ }^{102}$ It is most important that the Supreme Court bring clarity and uniformity and, above all, sympathy with its purposes to the administration of Section 75. Without this no efforts of Congress can succeed.

101. See (1937) 47 Yale L. J. 124.

102. 2 Morison and Comarager, Growth of the Asrenicasi Reptetic (1938) 204. 